
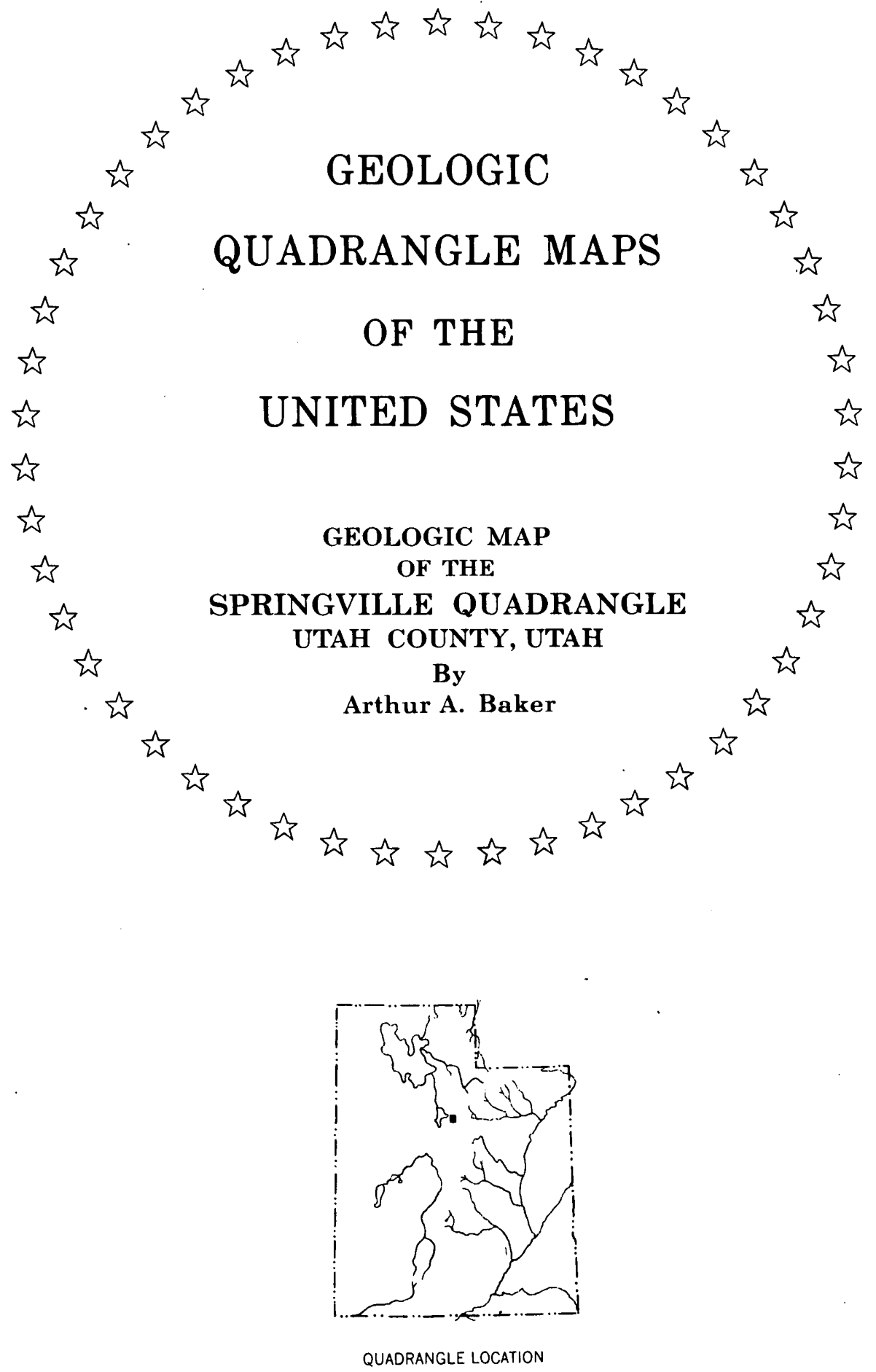


\title{
GEOLOGIC MAP OF THE SPRINGVILLE QUADRANGLE, UTAH COUNTY, UTAH
}

\author{
By \\ Arthur A. Baker
}

\section{INTRODUCTION}

The Springville quadrangle includes part of the Wasatch Range whose crest forms a sharp south-trending ridge in the northern part of the quadrangle. The high point is 11,068 feet at Provo Peak. The front of the range crosses the southwestern part of the quadrangle in the vicinity of Springville where the altitude of the valley floor is about 4,600 feet. All drainage is to the west into the Great Basin.

Folded and faulted rocks ranging in age from Precambrian to Mississippian crop out in the rugged west face of the range north of Springville whereas to the east the surface rocks in more than half the quadrangle are in the thick sequence of sandstone, quartzite, and limestone that is included in the Oquirrh Formation of Pennsylvanian and Permian age. Thrust faults are a prominent feature of the geologic structure of the range north and east of the Springville quadrangle, and the zone of thrusting is inferred to extend westward, at depth, beneath the quadrangle. The Springville thrust fault is presumed to be a part of this zone of thrust faulting and is the only surface exposure of a thrust fault in this zone within the quadrangle. The present structure of the range is a result primarily of a period of thrust faulting and associated folding followed by two periods of normal faulting, the latest of which produced the great escarpment forming the front of the range.

Geologic mapping was extended into the Springville quadrangle in 1949 as part of a regional mapping project in the central Wasatch Range that was initiated prior to World War II. Mapping in the quadrangle was accomplished mainly during parts of the summers of 1949 and 1952 although some additional data were gathered during brief visits in subsequent years. H. J. Bissell and P. E. Dennis assisted in developing knowledge of the stratigraphic sequence. Studies of fossils both in the field and the laboratory by J. Steele Williams, Mackenzie Gordon, Helen Duncan, L. G. Henbest, and R. C. Douglass provided invaluable assistance in dating and correlating the rocks.

\section{PRECAMBRIAN ROCKS}

Big Cottonwood Formation.-The oldest rocks exposed in the quadrangle are included in the Big Cottonwood Formation. They crop out in Slate Canyon and on the west face of Buckley Mountain. The total thickness of the rocks exposed in Slate Canyon is 1,347 feet. The rocks, consisting mainly of thin- to thick-bedded coarse-grained to conglomeratic quartzite with pebbles as much as 1 inch in diameter, range from light greenish gray to purple, in part with conspicuous banding of pinkish gray and deep purple to maroon. Thin to thick beds of phyllite, micaceous quartzite, and slate ranging from greenish gray to purple, purplish red and maroon are interbedded with the quartzite. $A$ bed of slate in the upper part of the exposure in Slate Canyon was formerly quarried for roofing slate. The rocks are correlated with the Big Cottonwood Formation of the type locality in Big Cottonwood Canyon (Crittenden and others, 1952, p. 3-4) on the basis of their stratigraphic position below typical tillite although they differ in lithology from the rocks at the type locality in the greater abundance of purple tones and their conglomeratic character.

Mineral Fork Tillite.-The Mineral Fork Tillite unconformably overlies the Big Cottonwood Formation and is a distinctive lithologic unit. It consists of a dark-grayishbrown, massive, poorly sorted material containing scattered pebbles and boulders as much as 1 foot in diameter embedded in a matrix of silt. The boulders are lightgray-weathering dark-gray dolomite, medium-gray quartzite, brown quartzitic sandstone, and altered igneous rocks. The tillite crops out in the quadrangle only in the lower walls of Slate Canyon near its mouth. It is 145 feet thick where measured near the Maple Flat fault on the north side of the canyon but wedges out southeastward before it reaches the bed of the canyon and is absent farther south at outcrops on the west face of Buckley Mountain. The Mineral Fork Tillite is at least 200 feet thick in Rock Canyon in the Bridal Veil Falls quadrangle to the north (Baker, 1972) and farther north in the Wasatch Range it is a thick unit between the Big Cottonwood and Mutual Formations of Precambrian age (Crittenden and others, 1952 , p. 4). In the Springville quadrangle it is overlain unconformably by the Tintic Quartzite of Cambrian age.

\section{CAMBRIAN SYSTEM}

Tintic Quartzite.-The Tintic Quartzite is white to tan on fresh surfaces and weathers light brown or rusty. It consists of rounded fine to coarse sand grains with streaks of quartz pebbles; pebbles as much as 2 inches in diameter are common in the lower part; generally the base contains boulders of quartz. The top 90 feet of the formation contains thin beds of greenish phyllite interbedded with the quartzite forming a gradational contact with the overlying Ophir Formation. As measured in Slate Canyon, the formation is 1,170 feet thick. It is included in the Cambrian on the basis of its regional stratigraphic relationships; it unconformably overlies rocks of Precambrian age and grades into the overlying Ophir Formation of Middle Cambrian age.

Ophir Formation.-The Ophir Formation is a soft shaly unit at the top of the ledge-forming Tintic Quartzite. It consists of olive-green micaceous shale with some thin beds of greenish sandstone and yellow to brown mottled limestone. The boundary between the Ophir Formation and the overlying Maxfield Limestone is gradational and may not have been picked consistently at the same horizon. The thickness of the Ophir Formation was measured on the north side of Slate Canyon as 250 feet but is 100 feet or less at other places.

On the basis of fossils collected from the Ophir Formation in the Wasatch Range north of the Springville quadrangle the formation is assigned to the Middle Cambrian (Baker and Crittenden, 1961).

Maxfield Limestone.-The Maxfield Limestone consists mainly of thin-bedded light- to dark-gray limestone but with some beds of massive light-gray limestone and dolomite. The limestone beds are more or less intensely mottled in shades of yellow, brown, or gray. Local beds of lime- 
stone are oolitic or pisolitic. The thickness of the Maxfield Limestone varies beneath the unconformity that separates it from the overlying Fitchville Formation. The maximum observed thickness in the Springville quadrangle is about 850 feet approximately $1 / 2$ mile north of the mouth of Little Rock Canyon. About $1 \frac{1 / 2}{}$ miles farther north the formation is about 350 feet thick south of Buckley Draw. In Rock Canyon in the next quadrangle to the north the thickness of the formation was measured as 597 feet.

Trilobites collected from the Maxfield Limestone 100 to 160 feet above the base near the stream bed in Rock Canyon included Kootenia sp., Dolichometopsis sp., and Spencia 'sp. as identified by A. R. Palmer and assigned by him to the Middle Cambrian.

\section{MISSISSIPPIAN SYSTEM}

Fitchville Formation.-The Fitchville Formation is the lowest unit of a thick series of mainly calcareous rocks of Mississippian age. It rests unconformably upon rock of Middle Cambrian age.

At most places a bed of sandstone or grit a few inches to 20 feet thick is present at the base of the formation. It is gray to brown, coarse grained, locally conglomeratic, and contains quartz pebbles as much as $3 / 4$ inch in diameter. The quartz grains and clasts are commonly frosted as if windblown. The sandstone is silicified locally but commonly is at least in part carbonate cemented. The rest of the formation consists mainly of gray, thin- to thickbedded dolomite that weathers light gray and forms a prominent ledge. Some darker gray limestone is interbedded with the dolomite near the top of the formation. In contrast to most of the other limestone of Mississippian age, chert is virtually absent from the Fitchville Formation. Walnut-sized vugs are common, some of which have been filled with calcite. The thickness of the Fitchville Formation is 170 feet as measured in Slate Canyon, about 100 feet thick in the vicinity of Toad Head south of Slate Canyon, and 265 feet thick in Rock Canyon in the Bridal Veil Falls quadrangle (Baker, 1972).

Formerly correlated with the Jefferson Dolomite of Devonian age, the formation has been reassigned to the Lower Mississippian on the basis of additional fossil collections and a study of all available fossil material; it is now correlated with the Fitchville Formation of the type locality in the East Tintic Mountains (Morris and Lovering, 1961, p. 82).

Gardison Limestone.-The Gardison Limestone crops out in the northwestern part of the Springville quadrangle. The discontinuous belt of outcrop crosses Slide and Slate Canyons and extends south along the west face of Buckley Mountain to the mouth of Little Rock Canyon. It also is present in isolated outcrops in downdropped blocks along the Wasatch fault zone at the front of the range.

The Gardison Limestone is composed of limestone mainly in very thin beds but with a few massive beds. The rock is mainly medium gray to very dark gray on fresh surfaces but generally weathers to a slate gray. Some of the thinbedded limestone is silty and weathers into thin pinkishgray flakes. Gray, buff, light-brown, or black chert is abundant in some units but scarce or absent in others. The chert occurs as stringers or blebs along bedding planes or as rounded masses as much as 2 inches in diameter: In the outcrop, a steplike profile tends to be produced by thick cliff-forming units alternating with slope-forming units. Some beds are highly fossiliferous. 'The formation is 900 feet thick as measured in Slate Canyon and in Rock
Canyon about 1 mile north of the Springville quadrangle, but at both localities some thickening may have occurred at the apex of sharp folds.

The Gardison Limestone is of Early Mississippian age. Its type locality is in the Tinctic district, Utah (Morris and Lovering, 1961, p. 89).

Deseret Limestone.-The Deseret Limestone conformably overlies the Gardison Limestone and differs from it in being thicker bedded and broadly banded in light and dark gray. The Deseret consists of interbedded light- to dark-gray limestone and dolomite generally with tan to black chert which is abundant in some beds. Large crinoid stems and both cup and colonial corals are common and locally are abundant. The thickness of the formation is 575 feet as measured along the bed of Slate Canyon. The Deseret Limestone is generally included in the Upper Mississippian. Although part of the formation in the vicinity of American Fork was formerly considered to be of Early Mississippian age (Baker and Crittenden, 1961), the entire formation is now placed in the Upper Mississippian (Mackenzie Gordon, oral commun., 1972).

Humbug Formation.-The Humbug Formation forms a broad belt of outcrop that extends across the head of Slate and Slide Canyons, along the crest of Buckley Mountain, and southward across the head of Little Rock Canyon to the front of the Wasatch Range northeast of Springville. The Humbug is also present in a series of west-dipping fault plates along the front of the range. The main outcrop on Buckley Mountain is abnormally wide because of folding and related faulting.

The Humbug Formation consists of light- to mediumgray thin- to thick-bedded limestone containing gray to tan chert interbedded with buff to gray, fine- to coarse-grained limy sandstone. The brown-weathering sandstone interbedded with gray-weathering limestone imparts a brown and gray banding to the outcrop of this formation that distinguishes it from other parts of the thick sequence of predominantly limy beds. The base of the formation is placed at the base of the lowest sandstone bed which may not occur everywhere at precisely the same stratigraphic position.. The thickness of the Humbug Formation is 520. feet as measured in Rock Canyon about 1 mile north of the Springville quadrangle.

Great Blue Limestone.-The Great Blue Limestone crops out in a prominent medial ridge between lateral tributaries at the head of Slate Canyon and in a narrow belt extending. southward to the mountain front near the northeast corner of Springville.

The Great Blue Limestone overlies the Humbug Formation with a conformable contact but with a marked change in lithology. The limestone of the Great Blue is characteristically very thin bedded, dark gray to black, weathering medium to light gray, and contains some black chert in nodules and thin beds. Beds of black shale as much as 50 feet thick are interbedded with the limestone and may represent lateral gradation from limestone through shaly limestone to shale. The limestone tends to break into thin. flakes that commonly are pinkish on weathered surfaces. Near the base, thin beds of olivebrown-weathering dark-gray quartzite are generally present interbedded with black shale and shaly limestone. The thickness of the Great Blue Limestone is 2,800 feet as measured at the head of Rock Canyon about a mile north of the quadrangle boundary. The full thickness of the formation is exposed near the north boundary of the quadrangle. Because of faulting, only the upper part of 
the formation extends south through Horse Mountain. Farther south only the lower part of the formation crops out above the Springville thrust fault.

\section{MISSISSIPPIAN AND PENNSYLVANIAN SYSTEMS}

Manning Canyon Shale.-The Manning Canyon Shale consists mainly of brown to black shale with numerous thin beds of light-brown-weathering gray fine-grained sandstone and some lenses or beds of orange-brownweathering grit. One or more thick beds of gray limestone with abundant black chert are-interbedded with the shale. The total thickness of the Manning Canyon Shale is 1,650 feet as measured at the head of Rock Canyon about 2 miles north of the Springville quadrangle. At that locality, a bed of limestone 90 feet thick is about 750 feet above the base of the formation. Similar limestone beds occur in the formation in the Springville quadrangle, but it is not clear whether isolated outcrops are part of a continuous bed or are limestone lenses in the shaly beds. The limestone, bed at Rock Canyon contains marine fossils identified by Mackenzie Gordon as of Pennsylvanian age whereas the shale 50 to 75 feet below the limestone contains marine fossils which were identified by him as Mississippian in age (Baker, 1964b). The contact of the Manning Canyon Shale and the underlying Great Blue Limestone appears to be conformable with interbedded brown sandy and silty beds and thin beds of brown-weathering gray quartzite resting upon the thin-bedded gray to black limestone of the Great Blue. The upper part of the Manning Canyon Shale is absent in outcrop in the Springville quadrangle because of faulting, but in the quadrangle to the north the contact with the overlying Oquirrh Formation is gradational.

\section{PENNSYLVANIAN AND PERMIAN SYSTEMS}

Oquirrh Formation.-The Oquirrh Formation forms the bedrock of almost the entire eastern half of the quadrangle. The lowest unit is the Bridal Veil Limestone Member which is 1,245 feet thick as measured near the mouth of the canyon of the Provo River in the quadrangle to the north. Approximately the upper half of the member crops out east of the West Aspen Grove fault in the northern part of the Springville quadrangle, and nearly the full thickness of the member crops out in an overturned position beneath the Springville thrust fault at the mountain front northeast of Springville. The member consists of thin-to thick-bedded, medium-gray to black limestone containing much brown to black chert; some beds are abundantly fossiliferous. It is of Early Pennsylvanian age.

The lower sandy member of the Oquirrh Formation is about 3,250 feet thick and includes the rocks between the top of the Bridal Veil Limestone Member and the base of the Shingle Mill Limestone Member. These rocks are mainly gray to tan limy to quartzitic sandstone with interbedded gray to black, cherty, thin- to thick-bedded, in part sandy, limestone. The age of the member ranges from Atokan to Des Moinesian.

The Shingle Mill Limestone Member is the lower of two thick beds of limestone that extend into the quadrangle from the north and crop out along Corral Mountain. It reappears at the surface and forms the walls of a gorge along Spring Canyon. The Shingle Mill Limestone Member consists of thin-bedded gray to black limestone containing abundant black chert and locally abundant fossils. It is 200 to 400 feet thick. The limestone contains fossils of Des Moinesian age, and the member marks the approximate top of rocks of that age.

The upper member of the Oquirrh Formation consists of gray to tan, fine- to medium-grained limy to quartzitic sandstone with some beds of thin- to thick-bedded gray to black limestone. A prominent bed of limestone about 50 feet thick that crops out high on the south side of Power House Mountain and across Hobble Creek on the north side of Grindstone Ridge is about 8,000 feet above the base of the member. The total thickness of the upper member is about 18,000 feet of which only about the lower 9,000 feet crops out in the Springville quadrangle. The rocks are of Pennsylvanian and Permian age ranging from Missourian to Virgilian and Wolfcampian.

- Fusulinids "are "abundant" in the "Oquirrh Formation. Because the dating of the rocks and much of the structural interpretation depend upon the fusulinid collections and their identification, a register of the collections is given.

\section{TERTIARY SYSTEM}

Flagstaff Limestone.-The Flagstaff Limestone is present in two small isolated outcrops in the southeast quarter of the quadrangle. White limestone and grit with abundant algal concretions form a thin cap on a ridge at the head of Lions Canyon and cover a small area on the ridge east of Grindstone Canyon. A few rounded pebbles associated with the limestone at the latter locality and on the crest of Grindstone Ridge near the N1/4 corner sec. 8 suggest the western featheredge of the thick conglomerate of the Price River Formation that underlies the Flagstaff Limestone a few miles to the east.

\section{PLEISTOCENE AND HOLOCENE}

The southwestern part of the quadrangle includes a part of the basin of ancient Lake Bonneville and sediments deposited in the lake cover most of the floor of the broad valley. The terrace formed at the high-level Bonneville stage of the lake is a conspicuous feature along the mountain front. The geology of the sediments deposited in the lake in the vicinity of Springville has been described by Bissell (1963).

Surficial deposits of several types occur at various places in the quadrangle. In addition to the sediments of Lake Bonneville, alluvial fill along the stream valleys, alluvial cones at the mouths of several canyons, landslides, and moraine and glacial-outwash deposits are common features. Landslides are especially notable on the front of the range north of Slide Canyon and on the south side of Slate Canyon.

Moraines and outwash from glaciers that formed in cirques on the east side of Corral Mountain cover extensive areas from Whittemore Canyon on the north to Pole Heaven on the south. Small moraines are present at the head of the Slate Canyon on the west face of Corral Mountain and on the east face of Buckley Mountain. A moraine deposited by a glacier originating in a cirque on the east side of Spanish Fork Peak 2 miles south of the quadrangle boundary reached Maple Canyon at the mouth of its Right Fork.

\section{STRUCTURE}

The general structure of the surface rocks of the Springville quadrangle is a huge faulted dome occupying the northwest part of the quadrangle and a faulted eastdipping monocline occupying the eastern half of the quadrangle. The structural relations are the result of a succession of major orogenic episodes. A period dominated by folding and thrust faulting (Sevier orogeny, Armstrong, 1968 ) produced an ancestral mountain mass, that extended westward from the vicinity of the present range. Material eroded from this uplift was deposited to form thick formations of Late Cretaceous and early Tertiary age in the region to the east. Renewed orogeny is reflected by a series 
of north-trending normal faults that are younger than the thrust faults but older that the present topography. A third period of orogeny involving large-scale normal faulting along the front of the range has continued essentially to the present time and has elevated the mountain range to its present position.

Thrust faults are important elements of the structure of the Wasatch Range north of the Springville quadrangle and the Charleston zone of thrust faults is believed to underlie part of the range (Baker, 1959, 1964a, b; Baker and Crittenden, 1961). Although the Springville thrust fault is the only thrust fault to reach the surface here, it is considered to be part of the Charleston zone of related thrust faults and is inferred to underlie the entire quadrangle as indicated on the cross sections. Crumpling, arching, and overturning are associated with the Springville thrust fault and the great fold through Buckley Mountain (section B-B') which is well exposed in the walls of Slate Canyon, is believed to have its origin in movement along this zone.

Some of the steep normal or reverse faults associated with the Buckley Mountain dome such as the Horse Mountain fault also doubtless originated during the thrust movement. The West Aspen Grove fault, however, is a major normal fault that has been traced for 20 miles. It offsets the thrust faults in the Aspen Grove quadrangle (Baker, 1964a) and is therefore younger than the thrusting. The West Aspen Grove fault follows the west side of the range north to Rock Canyon in the quadrangle to the north beyond which it follows the east side of the range. Nowhere is there evidence of a direct effect on the topography. Moreover, it appears to terminate against a fault block of the Wasatch fault system at its southern end. Clearly it is part of a fault system intermediate in age between the thrust faulting and the normal faulting on the front of the range. A series of north-trending normal faults in the east half of the quadrangle may be part of this intermediate system. Among the larger of these faults are the Spring Creek fault, the Maple Canyon fault which follows the Right Fork of Maple Canyon north from the vicinity of Spanish Fork Peak in the quadrangle to the south, northward across Hobble Creek and Pole Heaven and the Hobble Creek fault. The Hobble
Creek fault follows the Left Fork of Hobble Creek north from its junction with the Right Fork of Hobble Creek and extends to Bartholomew Canyon and beyond. In the lower part of Bartholomew Canyon, a sliver of the lower sandy member of the Oquirrh Formation appears to be a horst bounded by the branches of the Hobble Creek fault (section $\mathbf{A}-\mathbf{A}^{\prime}$ ). A notable displacement of about 1,000 feet. of the Flagstaff Limestone across the Left Fork of Hobble Creek is due to the Hobble Creek fault. In lower Bartholomew Canyon the west fault of the divided Hobble Creek fault appears to have large displacement as paleontologic evidence indicates that rocks of relatively late Missourian age on the west are downdropped against rocks of late Des Moinesian age on the east.

The west front of the Wasatch Range is an escarpment produced by folding and faulting. Rocks that crop out high on the mountains are dropped to valley level along faults dipping $30^{\circ}-40^{\circ} \mathrm{W}$. and commonly form westerly dipping plates resting on much older rocks. Along the face of Buckley Mountain, limestones of Mississippian age are in fault contact with rocks of Cambrian and Precambrian age. South of the Springville thrust fault, younger rocks of the Oquirrh Formation have a similar relationship with older rocks of the same formation, but south of Maple Canyon a single fault with similar dip seems to follow the foot of the faceted spurs. The aggregate displacement along the front of the range due to faulting and folding is over 5,000 feet along the face of Buckley Mountain which is comparable to displacements observed elsewhere along the front of the range (Baker, 1959, p. 155-157).

The relative ages of the folding and faulting that have affected the Wasatch Range have been discussed elsewhere (Baker, 1959; Baker and Crittenden, 1961; Baker, 1964a). In summary, the episode of thrust faulting with its associated folding and normal faulting reflects the Sevier orogeny in Late Cretaceous time; an episode of normal faulting occurred subsequent to the thrust faulting but before the close of volcanic activity in the area, hence, of Eocene age or later; the flexing and faulting that accounts for so much of the present relief on the face of the range is very recent and has continued to the present.

\section{REFERENCES CITED}

Armstrong, R. L., 1968, Sevier orogenic belt in Nevada and Utah: Geol. Soc. America Bull., v. 79, no. 4, p. 429-458.

Baker, A. A., 1959, Faults in the Wasatch Range near Provo, Utah, in Guidebook to the geology of the Wasatch and Uinta Mountains transition area: Intermountain Assoc. Petroleum Geologists, 10th Ann. Field Conf., Guidebook, p. 153-158.

1964a, Geology of the Aspen Grove quadrangle, Utah: U.S. Geol. Survey Geol. Quad. Map GQ-239.

$1964 \mathrm{~b}$, Geology of the Orem quadrangle, Utah: U.S. Geol. Survey Geol. Quad. Map GQ-241.

- 1972, Geologic map of the Bridal Veil Falls quadrangle, Utah: U.S. Geol. Survey Geol. Quad. Map GQ-998.
Baker, A. A., and Crittenden, M. D., Jr., 1961, Geology of the Timpanogos Cave quadrangle, Utah: U.S. Geol. Survey. Geol. Quad. Map GQ-132.

Bissell, H. J., 1963, Lake Bonneville: Geology of Southern Utah Valley, Utah: U.S. Geol. Survey Prof. Paper 257-B, p. 101-130.

Crittenden, M. D., Jr., Sharp, B. J., and Calkins, F. C., 1952, Parley's Canyon to the Traverse Range, in Geology of the central Wasatch Mountains, Utah: Utah Geol. Soc. Guidebook no. 8, p.1-37.

Morris, H. T., and Lovering, T. S., 1961, Stratigraphy of the East Tintic Mountains, Utah: U.S. Geol. Survey Prof. Paper 361, 145 p. 
Register of diagnostic fusulinid collections from Oquirrh Formation, Springville quadrangle, Utah

[Identifications and age determinations by L. G. Henbest and R. C. Douglass]

\section{USGS}

colln. no.

f 24383

f 24394

24393

f24391-2

f24384-5

f24386 to

f 24390

f 24372

f24371

f 24370

f 13172

f9291

f9695

$\mathrm{f} 13173$

f24406

f 24402-3

f24404

f 24405

f9696

f9598

f 24367

f24395

f 24368

24369

f 9613

$\mathrm{f} 9611$
$\mathrm{f} 9612$

f24396

f9604

f 9601

f9602

f1172

f9615,

f24397

f9599

f 24401

f9623

f24398

f24399

f 24400

f9606

f9607

f 9608

f9609

f9620

f9621

f9626

f9625

f9624

f 9600

f9627
Location

(Distance from north and west Altitude section lines, in feet)

T. 7 S., R. 3 E.

Sec. 11, 4,800 S., 4,650 E.

Sec. 12, 4,400 S., 2,500 E.

Sec. $12,4,600$ S., $2,500 \mathrm{E}$

Sec. 12, 5,200-5,400 S., $2,000-2,150 \mathrm{E}$.

Sec. 13, 350 S., 450 E.

Sec. 13, 0-500 S., 1,050$2,000 \mathrm{E}$.

Sec. 14, 3,100 S., 4,600 E.

Sec. $14,4.500$ S., 4,600 E.

Sec. 26,450 S., 3,800 E.

Sec. $26,4,500$ S., $1,550 \mathrm{E}$.

Sec. 27, 5,100 S., 3,800 E.

Sec. 34,100 S., 3,250 E.

Sec. 35,850 S., 250 E.

Sec. 35, 2,500 S., 2,125 E.

Sec. 35, 4,325 S., 2,400 E.

Sec. $35,3,650$ S., 2,550 E.

Sec. $35,3,000$ S., 2,900 E.

Sec. $35,2,900$ S., 4,050 E.

Sec. 35, 5,000 S., 4,050 E.

Sec. 35, 3,275 S., 5,300 E.

T. 7 S., R. 4 E

Sec. 8, 3,500 S., 1,900 E.

Sec. $17,4,850$ S., 2,850 E.

Sec. $17,1,550$ S., 825 E.

Sec. $19,3,400$ S., 0 E.

Sec. 20, 3,450 S., 3,400 E.

Sec. $20,5,150$ S., 150 E.

Sec. $20,2,400$ S., 4,550 E.

Sec. $29,2,150$ S., 3,300 E.

Sec. 31,150 E. of $S 1 / 4$ cor.

Sec. $32,4,050$ S., 1,500 E.

T. 8 S., R. 3 E.

Sec. 1, 2,000 S., 4,000 E.

Sec. 1, 1,400 S., 3,250 E.

Sec. 1, 900 S., 150 E.

Sec. 2, 1,350 S., 4,800 E.

Sec. 12, 1,000 S., 3,325 E.

Sec. 12, 2,100 S., 3,100 E.

Sec. 12, 2,200 S., 3,400 E.

5,340

Sec. 12, 2,800 S., 3,050 E.

5,280

T. 8 S., R. 4 E.

Sec. 5, 400 S., 2,900 E.

5,270

Sec. 5, 700 S., 3,200 E.

5,485

Sec. 5, 1,000 S., 3,300 E.

5,565

Sec. 5, 1,700 S., 3,850 E.

5,845

Sec. 5, 6,100 S., 500 E.

7,040

Sec. 5, 6,050 S., 350 E.

7,140

Sec. 6, 5,300 S., 5,250 E.

7,500

Sec. 6, 7,050 S., 2,750 E.

Sec. 6, 7,300 S., 1,050 E.

Sec. $6,1,400$ S., 400 E.

Sec. $7,1,950$ S., 2,800 E.

(ft)

7,150

6,540

5,060

5,760
Identification

Age

Millerella sp., Beedeina sp.

do.

do.

do.

do.

Fusulinella sp., Beedeina sp.

do.

Beedeina sp.

Pseudostaffella sp., Fusulinella sp. do.

Fusulinella sp., Beedeina sp.

Millerella sp., Pseudofusulinella sp.

Schubertella sp. do.

do.

Millerella sp., Pseudostaffella sp.

Schubertella? sp., Pseudofusulinella sp.

Kansanella sp., Triticites sp. aff. $T$. springvillensis

Beedeina sp.

Millerella sp., Pseudofusulinella sp.

Triticites sp. aff. T. springvillensis do.

do.

Kansanella sp.

Triticites sp. aff. $T$. springvillensis

Kansanella sp., Triticites sp.

Triticites sp. of Thompson and Bissell 1954

Triticites sp. aff. $T$. grangerensis

Millerella sp., Kansanella sp.,

Triticites sp. aff. T. ohioensis

Triticites sp.

Schubertella sp., Triticites sp. aff.

T. cellamagnus

Millerella sp., Schubertella? sp.,

Pseudofusulinella sp., Triticites sp.

Triticites sp. of Thompson and Bissell 1954

Pseudofusulinella sp., Kansanella sp.,

Triticites sp. aff. T. ohioensis

Schubertella sp., Pseudofusulinella sp., Triticites sp. of Thompson and Bissel 1954, Triticites sp. aff. $T$. ventricosis

Triticites sp. of Thompson and Bissell 1954, Triticites sp. aff. T. meeki, T. sp. aff. $T$. ventricosis

Triticites sp. of Thompson and Bissell 1954, Triticites sp. aff. T. ventricosis

Schubertella sp., Triticites sp. of Thompson and Bissell 1954

Schubertella sp., Pseudofusulinella sp., Triticites sp. aff. T. ventricosis

Pseudofusulinella sp., Triticites sp. of Thompson and Bissell 1954,

Pseudofusulina sp.

Triticites sp. aff. T. ventricosis,

Dunbarinella? sp.

Triticites sp. of Thompson and Bissell 1954, $T$. sp. aff. $T$. meeki

Pseudofusulinella sp., Triticites sp. aff. T. meeki, Dunbarinella? sp.

Schubertella sp., Triticites sp. aff.

T. meeki, Dunbarinella? sp.
Millerella sp., Pseudofusulinella sp.

Millerella sp., Triticites sp.

Millerella sp., Triticites sp. aff.

$T$. springvillensis

Kansanella sp.
Des Moinesian

Do.

Do.

Do.

Do.

Do.

Do.

Do.

Atokan

Do.

Des Moinesian

Des Moinesian (?)

Atokan (?)

Do.

Des Moinesian (?)

Des Moinesian (?)

Missourian

Des Moinesian

Des Moinesian(?)

Missourian

Do.

Do.

Do.

Do.

Wolfcampian

Virgilian (?)

Missourian

Do.

Wolfcampian

Missourian

Wolfcampian

Missourian

Wolfcampian

Do.

Do.

Do.

Do.

Do.

Do.

Do.

Do.

Do.

Des Moinesian(?) Missourian

Do.

Do. 